\title{
Impact of Short-Term Combined Antiretroviral Therapy on Brain Virus Burden in Simian Immunodeficiency Virus-Infected and CD8 ${ }^{+}$ Lymphocyte-Depleted Rhesus Macaques
}

\author{
Lakshmanan Annamalai, ${ }^{*}$ Veena Bhaskar, ${ }^{\dagger}$ \\ Douglas R. Pauley, ${ }^{*}$ Heather Knight, ${ }^{*}$ \\ Kenneth Williams, ${ }^{\mp}$ Margaret Lentz, ${ }^{\dagger}$ Eva Ratai, ${ }^{\dagger}$ \\ Susan V. Westmoreland, ${ }^{*}$ R. Gilberto González, ${ }^{\dagger}$ \\ and Shawn P. O'Neil*

\begin{abstract}
From the Division of Comparative Pathology," the New England Primate Research Center, Harvard Medical School, Southborough; Neuroradiology, ${ }^{\dagger}$ Athinoula A. Martinos Center for Biomedical Imaging, Massachusetts General Hospital, Charlestown; and the Department of Biology, ${ }^{\ddagger}$ Boston College, Chestnut Hill, Massachusetts
\end{abstract}

Antiretroviral drugs suppress virus burden in the cerebrospinal fluid of $\mathrm{HIV}$-infected individuals; however, the direct effect of antiretrovirals on virus replication in brain parenchyma is poorly understood. We investigated the effect of short-term combined antiretroviral therapy (CART) on brain virus burden in rhesus monkeys using the CD8-depletion model of accelerated simian immunodeficiency virus (SIV) encephalitis. Four monkeys received CART (consisting of the nonpenetrating agents PMPA and RCV) for four weeks, beginning 28 days after SIV inoculation. Lower virus burdens were measured by real-time RT-PCR in four of four regions of brain from monkeys that received CART as compared with four SIV-infected, untreated controls; however, the difference was only significant for the frontal cortex $(P<0.05)$. In contrast, significantly lower virus burdens were measured in plasma and four of five lymphoid compartments from animals that received CART. Surprisingly, despite normalization of neuronal function in treated animals, the numbers of activated macrophages/ microglia and the magnitude of TNF- $\alpha$ mRNA expression in brain were similar between treated animals and controls. These results suggest that short-term therapy with antiretrovirals that fail to penetrate the blood-cerebrospinal fluid barrier can reduce brain virus burden provided systemic virus burden is suppressed; however, longer treatment may be required to completely resolve encephalitic lesions and microglial activation, which may reflect the longer half-life of the principal target cells of HIV/SIV in the brain (macrophages) versus lymphoid tissues (T lymphocytes). (Am J Pathol 2010, 177:777-791; DOI: 10.2353/ajpatb.2010.091248; DOI: 10.2353/ajpath.2010.091248)

Human immunodeficiency virus (HIV) infects the central nervous system (CNS) in addition to lymphoid tissues, which can lead to the development of a variety of neurological conditions that are collectively referred to as HIVassociated neurocognitive disorders. HIV-associated dementia is the most severe neurological complication of AIDS, occurring in 20 to $30 \%$ of HIV-infected individuals before the advent of highly active antiretroviral therapy (HAART). ${ }^{1}$ HAART significantly reduces peripheral virus burden in most HIV-infected patients, and is credited with increasing the numbers of $\mathrm{CD}^{+}{ }^{+} \mathrm{T}$ lymphocytes, restoring immune function, and extending AIDS-free survival. ${ }^{2}$ Clinical studies have also correlated HAART with a reduction in the prevalence of HIV-associated dementia. ${ }^{3-8}$ Moreover, reports that neurologically impaired patients experience improvements in neuropsychological, cogni-

Supported in part by grants from the National Institutes of Health, National Institute of Neurological Disorders and Stroke, and National Center for Research Resources, including RR000150 (S.P.O.), NS048831 (to S.P.O.), NS050041 (R.G.G.), and NS40237 (K.W.).

Accepted for publication April 22, 2010.

Supplemental material for this article can be found on http://ajp. amjpathol.org.

Current address of L.A.: Department of Animal Resources, Oregon National Primate Research Center, Beaverton, OR; of S.P.O.: Pfizer Inc., Andover, MA.

Address reprint requests to Susan V. Westmoreland, V.M.D., Division of Comparative Pathology, New England Primate Research Center, One Pine Hill Drive, Southborough, MA 01772. E-mail: susan_westmoreland@ hms.harvard.edu. 
tive, and psychomotor functions and undergo normalization of alterations in brain metabolites after the initiation of HAART suggest that treatment may reduce the severity of neurological disease..$^{9-13}$ In addition, viral load in cerebrospinal fluid (CSF) usually decreases after the onset of HAART in treatment-naïve patients, despite poor penetration of the blood-brain and blood-CSF barriers by most antiretroviral agents. ${ }^{14-23}$

Nevertheless, despite clinical evidence supporting the efficacy of antiretroviral therapy for HIV-associated dementia, the prevalence of encephalitic and neurodegenerative lesions is often high in postmortem studies of AIDS patients who received HAART, ${ }^{24-27}$ and there is evidence of a renewed increase in the frequency of HIV encephalopathy (HIVE) in response to the greater prevalence of multidrug-resistant HIV strains, as well as the emergence of new variants of HIVE, like severe leukoencephalopathy. ${ }^{28,29}$ Moreover, there are neuroimaging and neuropsychological data indicating that there is progression of brain injury due to HIV despite HAART. ${ }^{30-32}$ Taken together, these observations suggest that while HAART may alleviate some of the neurological symptoms associated with HIV infection, current regimens fail to eliminate the virus from the CNS and long-term suppression of brain virus burden may be required before inflammatory and neurodegenerative lesions in the CNS subside. ${ }^{33,34}$

The detection of distinct viral variants in blood versus brain compartments in both antiretroviral-treated and naïve populations provides evidence that the CNS serves as an anatomical reservoir for HIV, ${ }^{35,36}$ and virus sequestered in anatomical sanctuaries like the CNS and male genital tract may pose a significant problem for the therapeutic eradication of HIV from infected individuals. ${ }^{37-41}$ Many antiretroviral agents, especially protease inhibitors, exhibit poor penetration across the blood-brain barrier (BBB); thus, therapeutic levels of these drugs are not usually established in the extracellular space of the brain. ${ }^{42,43}$ Furthermore, the activity of many protease inhibitors is several fold lower in chronically-infected macrophages as opposed to chronically infected lymphocytes, ${ }^{44}$ and productive lentiviral infection in the primate brain is confined almost exclusively to cells of macrophage lineage. ${ }^{45-47}$ Ongoing viral replication in the face of subtherapeutic concentrations of antiretroviral agents is likely to promote the expansion of drug-resistant viral clones, which could potentially repopulate peripheral lymphoid tissues as macrophages recirculate out of the CNS. ${ }^{41}$ A better understanding of the direct effects of antiretroviral therapy on brain virus burden and on the encephalitic and neurodegenerative lesions that correlate with HIV-associated neurocognitive disorders could facilitate the development of therapeutic strategies that are more effective at targeting the CNS; however, the inaccessibility of brain tissue impedes direct antemortem measurements of antiretroviral efficacy in the CNS.

SIV infection of Asian macaque monkeys serves as an excellent model for investigating the neuropathogenesis of HIVE. ${ }^{48-50}$ The incidence of encephalitis in macaques infected with conventional isolates and clones of SIV ranges from 18 to $32 \%,{ }^{51,52}$ however the frequency of SIV encephalitis (SIVE) can be increased to more than $80 \%$ in rhesus macaques that are infected after the depletion of $\mathrm{CD}^{+}$cells. ${ }^{47,53,54}$ In this study, we used the CD8 ${ }^{+}$celldepletion model of accelerated SIVE in rhesus macaques to compare the effect of short-term CART on brain versus peripheral (plasma and lymphoid tissue) virus burdens, using a therapeutic regimen consisting of one nucleoside and one nucleotide reverse transcriptase inhibitor, neither of which penetrate the BBB effectively. Longitudinal in vivo imaging and magnetic resonance spectroscopy (MRS) of these animals revealed a near normalization of neuronal metabolism with short-term CART. ${ }^{54}$ Given these findings, we also sought to evaluate the effect of short-term CART on macrophage activation and the expression of TNF- $\alpha$ mRNA transcripts in the brain parenchyma, two well-established surrogate markers of neuroinflammation during primate lentiviral encephalitis.

\section{Materials and Methods}

\section{SIV Inoculations, CD8 ${ }^{+}$Lymphocyte Depletions, and Antiretroviral Therapy}

Eight adult rhesus macaques were inoculated with SIVmac251 (20 ng of SIV p27 each) by the intravenous route. To increase the incidence of encephalitis, $\mathrm{CD}^{+}$cells were depleted with the anti-CD8 antibody CM-T807, which was administered subcutaneously (10 mg/kg) on day 6 after inoculation and intravenously ( $5 \mathrm{mg} / \mathrm{kg}$ ) on days 8 and 12 after inoculation. Four of the eight animals were randomly selected for CART and received subcutaneous injections of PMPA [(R)-9-(2-phosphonylmethoxypropyl) adenine] at $30 \mathrm{mg} / \mathrm{kg} /$ day and Racivir $[(+/-)$ $\beta$-2', 3'-dideoxy-5-fluoro-3'-thiacytidine] (RCV), at $10 \mathrm{mg} /$ $\mathrm{kg} /$ day, beginning day 28 after inoculation. All animals that received CART were euthanized 28 days after initiation of therapy; untreated control macaques were euthanized when they developed simian AIDS (SAIDS) (Table 1).

\section{Necropsy and Tissue Collection}

Complete necropsies were performed on all of the monkeys, and brain and lymphoid tissues were collected and fixed in 10\% neutral buffered formalin for histopathological examination, immunohistochemistry (IHC), and in situ hybridization (ISH). Matching tissue specimens were collected in RNAlater (Applied Biosystems/Ambion, Austin, TX) and frozen according to the manufacturer's instructions and stored at $-80^{\circ} \mathrm{C}$ for later RNA extraction. Formalin-fixed tissues were processed to paraffin blocks according to routine protocols, and paraffin sections were stained with hematoxylin and eosin for histopathological examination.

\section{Quantification of Viral RNA in Plasma and CSF}

Plasma was obtained by centrifugation of whole blood that had been collected in EDTA anticoagulant and was 
Table 1. Plasma and CSF Virus Load

\begin{tabular}{|c|c|c|c|c|c|c|c|c|}
\hline \multirow[b]{2}{*}{ Group } & \multirow{2}{*}{$\begin{array}{c}\text { Case } \\
\text { number }\end{array}$} & \multirow{2}{*}{$\begin{array}{l}\text { Age } \\
\text { (days) }\end{array}$} & \multirow{2}{*}{$\begin{array}{c}\text { NDI } \\
\text { (days) }\end{array}$} & \multicolumn{2}{|c|}{$\begin{array}{l}\text { Plasma virus load } \\
\left(\log _{10} \text { copies } / m l\right)\end{array}$} & \multicolumn{2}{|c|}{$\begin{array}{l}\text { CSF virus load } \\
\left(\log _{10} \text { copies } / m l\right)\end{array}$} & \multirow[b]{2}{*}{ Encephalitis } \\
\hline & & & & $21 \mathrm{dpi}$ & Terminal & $21 \mathrm{dpi}$ & $\overline{\text { Terminal }}$ & \\
\hline \multirow[t]{4}{*}{ Untreated } & 1 & 3116 & 70 & 7.7 & 6.7 & 4.8 & 6.00 & +++ \\
\hline & 2 & 3487 & 57 & 7.7 & 7.6 & 5.2 & 5.5 & +++ \\
\hline & 3 & 3489 & 63 & 7.1 & 7.7 & 4.5 & 4.3 & ++ \\
\hline & 4 & 4606 & 85 & 6.6 & 7.6 & 5.7 & 5.0 & ++++ \\
\hline \multirow[t]{4}{*}{ CART } & 5 & 4025 & 57 & 7.4 & 5.4 & 5.7 & 3.9 & - \\
\hline & 6 & 7584 & 57 & 7.1 & 6.1 & 6.1 & 5.9 & - \\
\hline & 7 & 3782 & 57 & 6.5 & 4.6 & * & 4.9 & - \\
\hline & 8 & 3778 & 57 & 7.2 & 5.8 & * & 5.4 & - \\
\hline
\end{tabular}

*Samples not available; Neuropathology scores for encephalitis severity: ++ mild, +++ moderate, ++++ severe, - absent. NDI, number of days postinfection upon which animal was sacrificed.

frozen and stored at $-80^{\circ} \mathrm{C}$ until analyzed. CSF was acquired from the cerebellomedullary cistern of anesthetized macaques at 21 days post inoculation (dpi) and immediately before euthanasia, and was snap-frozen and stored at $-80^{\circ} \mathrm{C}$ until analyzed. Virion-associated RNA was measured in plasma and CSF by real-time RT-PCR as previously described. ${ }^{55}$

\section{Cloning and in Vitro Transcription of SIVgag and TNF- $\alpha$}

The SIVmac239 gag coding sequence was subcloned by PCR from a plasmid that contained the 5'-portion of SIVmac239 into the pGEMTeasy vector (Promega Corp., Madison, WI). Rhesus macaque TNF- $\alpha$ was cloned using total RNA obtained from the spleen of a healthy animal. The cDNA was amplified using PCR and cloned into the pGEMTeasy vector. The clones were verified by sequencing both strands of DNA.

In vitro transcription reactions for the SIVmac239 gag, TNF- $\alpha$, and RPL13A genes were conducted using T7 RNA polymerase (Megascript kit, Applied Biosystems/ Ambion). Briefly, plasmid constructs were linearized with restriction enzymes, and in vitro transcription was performed for 7 hours at $37^{\circ} \mathrm{C}$ using $1 \mu \mathrm{g}$ of linearized plasmid as template. Plasmid DNA was digested with Turbo DNase (Applied Biosystems/Ambion), and the transcripts were purified on RNeasy spin columns (Qiagen, Valencia, CA) and eluted in RNase free water. Transcripts were stored in aliquots at $-80^{\circ} \mathrm{C}$ after the addition of RNase inhibitor (RNasin, Promega) at a concentration of 2 units $/ \mu$ l. The concentration of transcripts was determined using the QuanTi Ribo Green kit (Invitrogen Corp., Carlsbad, CA), and the copy numbers were calculated from the molecular mass of the transcripts. RNA standards were generated for each real-time RT-PCR reaction by serial dilution of the transcripts in RNase free water.

\section{Immunohistochemistry}

IHC was performed to detect macrophages, B Iymphocytes, CD8 ${ }^{+}$T Iymphocytes, and SIV-infected cells. Macrophages were localized using antibodies directed against CD68 (clone KP1, Dako Corp., Carpinteria, CA), Iba-1 (Wako Chemicals USA, Inc., Richmond, VA), and HLA-DR (clone CR3/43, Dako Corp.). B lymphocytes were identified with antibodies directed against CD20 (clone L26, Dako Corp.), while CD8 ${ }^{+}$T Iymphocytes were localized with antibody clone 1A5 (Vector Laboratories, Burlingame, CA). SIV-infected cells were identified with antibodies directed against SIVnef [clone KK75, Programe EVA Centre for AIDS Reagents, National Institute for Biological Standards and Control (NIBSC), UK] ${ }^{56}$ or the major capsid protein, SIVp27 [clone 183-H12-5C, National Institutes of Health (NIH) AIDS Research \& Reference Reagent Program]. ${ }^{57} \mathrm{IHC}$ reactions were performed on formalin-fixed paraffin-embedded sections of the frontal cortex, putamen, hippocampus, and brainstem, using a commercial kit (LSAB plus, DAKO Corp.). The tissue sections were deparaffinized in xylene and rehydrated through graded ethanol to distilled water. For CD68 and CD20 immunostaining, antigen retrieval was performed by microwaving the sections for 20 minutes in citrate buffer (DAKO Corp.) followed by incubation in 3\% $\mathrm{H}_{2} \mathrm{O}_{2}$ to block endogenous peroxidase activity. For antiCD8 immunostaining, deparaffinization, rehydration, and antigen retrieval were performed simultaneously in Trilogy solution (Cell Marque, Rocklin CA), using a pressure cooker. After 60 minutes of incubation with the respective primary antibody, the sections were sequentially treated with biotinylated secondary antibody and horseradish peroxidase-conjugated streptavidin. The chromogenic substrate 3, 3'-diaminobenzidine (DAB, DAKO Corp.) was used to localize antigen-antibody complexes. Tissue sections were counterstained with Mayer's hematoxylin (Sigma Aldrich, St. Louis, MO), cleared, and coverslipped with permanent mounting medium.

\section{ISH for SIV RNA}

The relative cell-associated virus burden was measured in four regions of brain parenchyma (frontal cortex, putamen, hippocampus, and brainstem) and mesenteric lymph nodes from each infected macaque in formalinfixed paraffin-embedded sections by ISH for SIV RNA, as described elsewhere. ${ }^{45}$ Tissue sections were deparaffinized in xylene and rehydrated in graded ethanol to 
diethyl pyrocarbonate (Sigma) treated water. Endogenous alkaline phosphatase activity was blocked with levamisole (Sigma). Tissue sections were hydrolyzed in $\mathrm{HCl}$ (Sigma), digested with proteinase K (Roche Diagnostics Corp., Indianapolis, IN), acetylated in acetic anhydride (Sigma), and hybridized overnight at $50^{\circ} \mathrm{C}$ with a digoxigenin-labeled antisense riboprobe which spans the entire genome of the SIVmac239 molecular clone of SIVmac251 (Lofstrand Labs, Gaithersburg, MD). The following day, tissue sections were washed extensively and bound probe was detected by $\mathrm{IHC}$, using alkaline phosphatase-conjugated sheep anti-digoxigenin $F(a b)$ fragments (Roche) and the chromogen nitroblue tetrazolium/ 5-bromo-4-chloro-3-indolyl-phosphate (NBT/BCIP, Roche). Sections were counterstained with nuclear fast red (Vector Labs, Burlingame, CA). Sections of brain from a rhesus macaque with SIVmac251 encephalitis served as both positive control (when incubated with SIV antisense probe) and negative control (when reacted with SIV sense probe). Additional negative controls included sections of brain from uninfected macaques reacted with SIV antisense probe.

\section{Computer Image Analysis}

SIV-infected cells and macrophages were enumerated in sections of brain tissue and lymph node biopsy specimens from each of the SIV-infected macaques by computer image analysis as described elsewhere. ${ }^{45}$ Images of tissue sections were captured without manipulation using an Olympus 3-CCD T60C color video camera mounted on an Olympus Vanox-SI microscope and analyzed using NIH Image $J$ software. For each anatomical compartment, virus burden was measured by counting the number of chromogen-positive cells per unit area $\left(\mathrm{mm}^{2}\right)$ on tissue sections that had been subjected to a carefully controlled ISH assay for SIV RNA; similarly, the numbers of chromogen-positive SIV-infected cells (in lymph node) and macrophages (in brain) per $\mathrm{mm}^{2}$ were quantified in tissue sections after IHC for SIVnef and CD68 or Iba-1, respectively. For each evaluation, particle size and threshold parameters were established on control sections of brain from infected and uninfected macaques that had been processed in parallel with experimental sections. The mean cell-associated virus burden for each anatomical compartment of brain (regional mean) and the average number of CD68 or Iba- 1 immunoreactive macrophages was determined for each SIV-infected macaque by counting the number of chromogen-positive cells in 20 random fields at 200x magnification, and dividing by the total area analyzed (reported as SIV +, CD68+, or Iba- $1+$ cells per $\mathrm{mm}^{2}$, respectively).

\section{Real-Time RT-PCR for SIVgag, TNF- $\alpha$, and} RPL13A

\section{RNA Isolation}

Total RNA was isolated from brain and lymphoid tissues collected in RNAlater using Trizol reagent (Invitrogen). Briefly, $75-100 \mathrm{mg}$ pieces of tissue were homoge- nized with a bead beater using 1-mm-diameter silica beads and $1.5 \mathrm{ml}$ Trizol. The aqueous phase was collected after adding of 0.2 volumes of chloroform to the homogenate and centrifuging at $8000 \times g$ for 5 minutes at $4^{\circ} \mathrm{C}$. One milliliter of $4 \mathrm{~mol} / \mathrm{L}$ guanidium thiocyanide and an equal volume of $70 \%$ ethanol were added to the aqueous phase and loaded on to a spin column. Oncolumn DNase treatment was performed to digest contaminating DNA, and the total RNA was eluted in RNase free water and stored at $-80^{\circ} \mathrm{C}$ after addition of two units $/ \mu$ l of recombinant RNase inhibitor (Promega).

\section{One-Step Real-Time RT-PCR}

Absolute quantification of SIVgag, TNF- $\alpha$ or RPL13A transcripts in samples of total RNA were performed using gene specific TaqMan probes (Applied Biosystems) and Taqman one-step RT-PCR master mix reagents (Applied Biosystems) on an ABI 7700 thermocycler in separate reactions. The reaction substrate, $100-500 \mathrm{ng}$ of total RNA, was combined with $200 \mathrm{nmol} / \mathrm{L}$ each of forward and reverse primers and $100 \mathrm{nmol} / \mathrm{L}$ of Taqman probe in a 50 $\mu l$ reaction (sequences for the primers and probe used are shown in Table 2). For mRNA copy number determination, stocks containing known copy numbers of SIVgag, TNF- $\alpha$, or RPL13A RNA transcripts that had been generated by in vitro transcription were serially diluted in RNase free water to create standards ranging from $10^{6}$ to $10^{1}$ copies. Both standards and test samples were run in duplicate. At the end of each run, the data were analyzed using the Sequence Detection version 1 software program (Applied Biosystems).

\section{Statistical Analyses}

A two-tailed, nonparametric Mann-Whitney U-test was used to compare numbers of activated macrophages in the brain, TNF- $\alpha$ expression, virus burden measured by ISH and real-time RT-PCR, and virus burden in plasma and CSF between control animals and animals that received CART. Significant differences were assumed for probability values of $P<0.05$.

\section{Results}

\section{Short-Term CART Significantly Reduces Plasma but Not CSF Virus Burdens}

Viral loads in plasma and CSF were measured by realtime RT-PCR at $21 \mathrm{dpi}$ and at necropsy and are reported as $\log _{10}$ SIVgag copies per $\mathrm{ml}$ (Table 1). The median plasma virus burden of animals that received CART decreased from $7.15 \log _{10}$ copies $/ \mathrm{ml}$ at $21 \mathrm{dpi}$ (before onset of treatment) to $5.60 \log _{10}$ copies $/ \mathrm{ml}$ after 28 days of therapy $(P<0.03)$. In contrast, plasma viral loads were unchanged between $21 \mathrm{dpi}$ and necropsy in macaques that did not receive CART (median plasma viral loads of 7.4 vs. $7.6 \log _{10}$ copies $/ \mathrm{ml}$, respectively; $P=0.88$ ). CSF viral loads were similarly unchanged between $21 \mathrm{dpi}$ and 
Table 2. Primers and Probes

\begin{tabular}{|c|c|c|}
\hline Accession number & Gene & Primers and probes used for TaqMan assay \\
\hline M33262 & SIV gag & $\begin{array}{l}\text { Forward: 5'-AGAAAGCCTGTTGGAGAACAAAGAAGG-3' } \\
\text { Reverse: 5'-AGTGTGTTTCACTTTCTCTTCTGCGTG-3' } \\
\text { Probe: } 6 \text { FAM-5'-CTGTCTGCCTCATCTGGTGC-3'-TAMRA }\end{array}$ \\
\hline NM_001047149 & $T N F-\alpha$ & $\begin{array}{l}\text { Forward: } 5{ }^{\prime}-\text { CTCTTCAAGGGCCAAGGCT-3' } \\
\text { Reverse: } 5 \text { '-GATGCGGCTGATGGTGTG-3' } \\
\text { Probe: } 6 \text { FAM-5'-CCCCTCCAACCATGTGCTCCTCA-3'-TAMRA }\end{array}$ \\
\hline FM208094 & RPL13A & $\begin{array}{l}\text { Forward: } 5{ }^{\prime} \text {-CGAGAAAGTTTGCCTATCTGGG*-3' } \\
\text { Reverse: } 5 \text { 5'-GGTGGTTGTCACTGCCTGGTA*-3' } \\
\text { Probe: } 6 \text { FAM-5'-CCTGGCTCACGAGGTTGGCTGG-3'-TAMRA }\end{array}$ \\
\hline
\end{tabular}

necropsy in untreated controls (median values of 5.00 and $5.25 \log _{10}$ copies $/ \mathrm{ml}$, respectively, $P=0.89$ ). Paired pre- (21 dpi) and posttherapy (terminal) CSF specimens were only available for two of the animals from the CART group, and while the CSF viral load decreased 1.8 logs during the 28-day treatment period in one macaque (Case 5), it was unchanged in the other animal. Thus, no conclusions could be drawn regarding the efficacy of CART on CSF virus burden in individual animals over time.

Terminal plasma virus burdens were significantly lower in animals that received CART than in untreated controls (median values of 5.6 vs. $7.6 \log _{10}$ copies $/ \mathrm{ml}$, respectively; $P<0.03$ ); however, terminal CSF viral loads were not significantly different between the CART and untreated groups (median values of 5.15 vs. $5.25 \log _{10}$ copies $/ \mathrm{ml}$, respectively; $P=0.69$ ) (Figure $1, \mathrm{~A}$ and $\mathrm{B}$ ). Thus, short-term CART was effective in reducing the systemic viral burden but not the quantity of viral RNA in the CSF compartment, suggesting that therapy was more
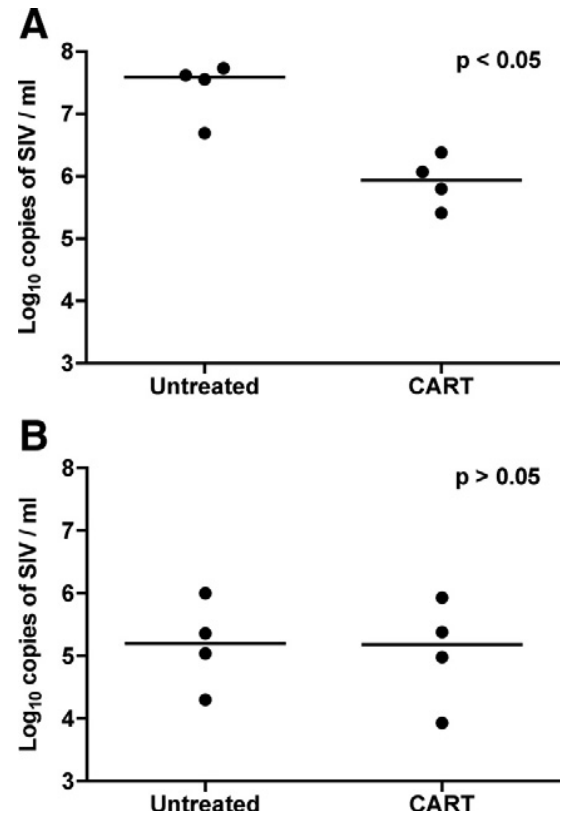

Figure 1. Viral load in terminal plasma and CSF. The terminal plasma viral load was significantly lower in animals that received CART than in untreated controls (A). In contrast, the quantities of viral RNA measured in CSF were similar between animals that received CART and untreated controls (B). Results are reported as $\log _{10}$ copies of SIV RNA/ml; horizontal bars indicate group median values. successful at suppressing viral replication in lymphoid tissues than in the central nervous system.

Comparison of plasma viral loads at $21 \mathrm{dpi}$ between the CART and control groups revealed no difference in systemic virus burden before the onset of therapy (median viral loads of 7.15 versus 7.40 , respectively; $P=$ 0.56). This was further supported by $\mathrm{IHC}$ for SIVnef on peripheral lymph nodes collected from all eight animals by surgical biopsy at $28 \mathrm{dpi}$ (Figure 2, A-C), as large numbers of productively infected cells were observed in sections of lymph node from each of the animals. Based on histomorphology, the infected cell populations in lymph nodes from all of the animals consisted primarily of lymphocytes and macrophages, with occasional multinucleated giant cells. Thus, similar high levels of systemic virus replication were present in all eight animals before the onset of CART.

\section{SIVE Lesions Were Not Present in Animals that Received CART}

Histopathological examinations were performed on H\&Estained sections from four regions of the brain (frontal cortex, basal ganglia, hippocampus, and brainstem) and from five hematopoietic/lymphoid tissues (mesenteric, inguinal and axillary lymph nodes, spleen, and bone marrow) from each of the animals. Neuropathological lesions characteristic of SIVE ${ }^{45,47}$ were observed in brain sections from all of the untreated control macaques and included perivascular accumulations of macrophages, multinucleated giant cells, microglial nodules, white matter vacuolation, mild meningitis, and choroid plexitis (Figure $3, \mathrm{~A}-\mathrm{F})$. Parenchymal lesions were present in both white and gray matter in macaque number 4 but were confined primarily to the white matter tracts in the other control animals. In contrast, lesions characteristic of SIVE were not observed in brain sections from the animals in the CART group; however, mild multifocal perivascular infiltrates of mononuclear inflammatory cells, morphologically consistent with lymphocytes, were present in all regions of brain examined from macaque number 8 . These lesions were highly atypical of SIVE, and subsequent IHC assays revealed that these perivascular infiltrates were predominantly composed of $\mathrm{CD} 2 \mathrm{O}^{+} \mathrm{B}$ lymphocytes rather than the macrophages and $T$ lymphocytes that are typical of SIVE, suggesting a different etiology (Supplemental Figure $\mathrm{S} 1$ at $h$ ttp://ajp.amjpathol.org). 

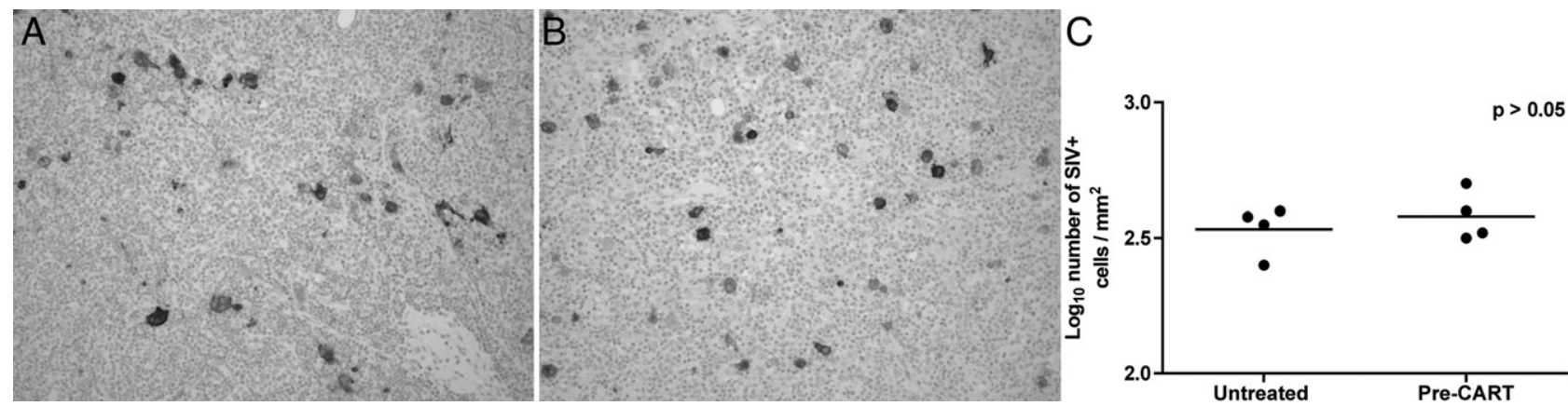

Figure 2. Productively infected cells are localized in the inguinal lymph nodes of animals at 28 dpi. Numerous productively infected cells were localized by IHC for SIVnef in inguinal lymph node biopsy specimens collected before the onset of CART at 28 dpi from all eight animals, including animals randomly assigned to the untreated control group (A) and the CART group (B). Quantitative image analysis for SIVnef confirms comparable levels of infection in peripheral lymph nodes at $28 \mathrm{dpi}$ before onset of CART $(\mathbf{C})$.

We used IHC to further characterize the brain lesions observed in control macaques. As expected, the microglial nodules and multinucleated giants cells expressed macrophage/microglia markers CD68, Iba-1, and HLA-DR and were active sites of viral replication, confirmed through the expression of SIV Nef by $\mathrm{IHC}$ (Figure 4, A-D). These results are similar to those described for SIVE lesions in monkeys in which $\mathrm{CD} 8^{+}$cells have not been depleted. ${ }^{47}$ Evaluation of peripheral lymphocytes by flow cytometry revealed that $\mathrm{CD} 8^{+}$cells were depleted from the systemic circulation of both groups of monkeys for nearly four weeks before they began to recover. ${ }^{54}$ We performed IHC for CD8 on sections of brain from all of the animals to investigate the impact of prior peripheral $\mathrm{CD}^{+}$cell depletion on $\mathrm{CD} 8^{+}$ cell populations in the CNS at necropsy. $\mathrm{CD} 8^{+}$cells were localized in brain sections from all animals in the CART group, which were sacrificed at $57 \mathrm{dpi}$, as well as from all controls, which lived for a slightly longer duration (median survival of 66.5 days) (data not shown). These findings indicate that at the time of necropsy, $\mathrm{CD}^{+}$cells were present in circulation and capable of transmigration across the blood-brain barrier and into the CNS, despite prior CD8 depletion.

The most significant lesion observed in the lymphoid organs was severe lymphoid depletion of the periarterial lymphoid sheaths of the spleen and paracortical regions of lymph nodes, which was present in lymphoid tissues from all of the monkeys. Follicular hyperplasia was also present in lymph nodes from animals in both groups, but was more established in macaques that received CART, while multinucleated giant cells were only observed in lymphoid tissues from the untreated controls (Supplemental Figure S2 at http://ajp.amjpathol.org). In summary, these histopathological and immunohistochemical data suggest that while all macaques had lesions in lymphoid tissues that were typical of SIV infection at the time of necropsy, only the four animals that did not receive CART developed SIVE.

\section{Monkeys that Receive CART Have Lower Brain Virus Burdens}

Two methods were used to evaluate the effect of short term CART on tissue virus burden in frontal cortex, puta- men, hippocampus, and brainstem. The cell-associated virus burden was measured in tissue sections by computer image quantification of productively infected cells that were localized by ISH for viral RNA. In addition, absolute copy numbers of virion-associated RNA were measured by TaqMan real-time RT-PCR.

Significantly fewer SIV-infected cells were localized by ISH in the frontal cortex and brainstem $(P<0.05)$ of animals that received CART than in untreated controls (Figure 5, A-D). Fewer SIV-positive cells were present in the hippocampus of animals that received CART as well, but the difference was not statistically significant $(P=$ $0.5)$; indeed, very few infected cells were localized in the hippocampus or putamen from either treated or control animals.

Absolute virus copy numbers were determined in total RNA isolated from the same four regions of brain by one step real-time RT-PCR using a TaqMan probe for SIVgag. Because the expression of RPL13A is unaltered in SIVE (manuscript in submission), we used RPL13A copy numbers in each specimen to normalize the input RNA in parallel reactions. Lower quantities of viral RNA were measured in all four regions of brain from animals that received CART than in untreated controls; however, the difference was statistically significant only in the frontal cortex $(P=0.03)$ (Figure 6, A-D). We found no correlation between viral load in CSF and the tissue virus burden in any of the regions of brain examined. Taken together, these data suggest that a short-term regimen of CART composed of agents with limited CNS penetrance was still successful at reducing brain virus burden. We hypothesized that the reduction in brain virus burden observed in animals that received CART reflected decreased recruitment of SIV-infected monocytes from peripheral blood as a result of antiretroviral-mediated suppression of systemic virus burden. Thus we sought further evidence that short-term CART was effective at reducing the virus burden in lymphoid tissues.

\section{Animals that Receive CART Have Significantly Lower Lymphoid Tissue Virus Burdens}

To study the effect of short-term CART on virus burden in bone marrow and peripheral lymphoid tissue, we quan- 

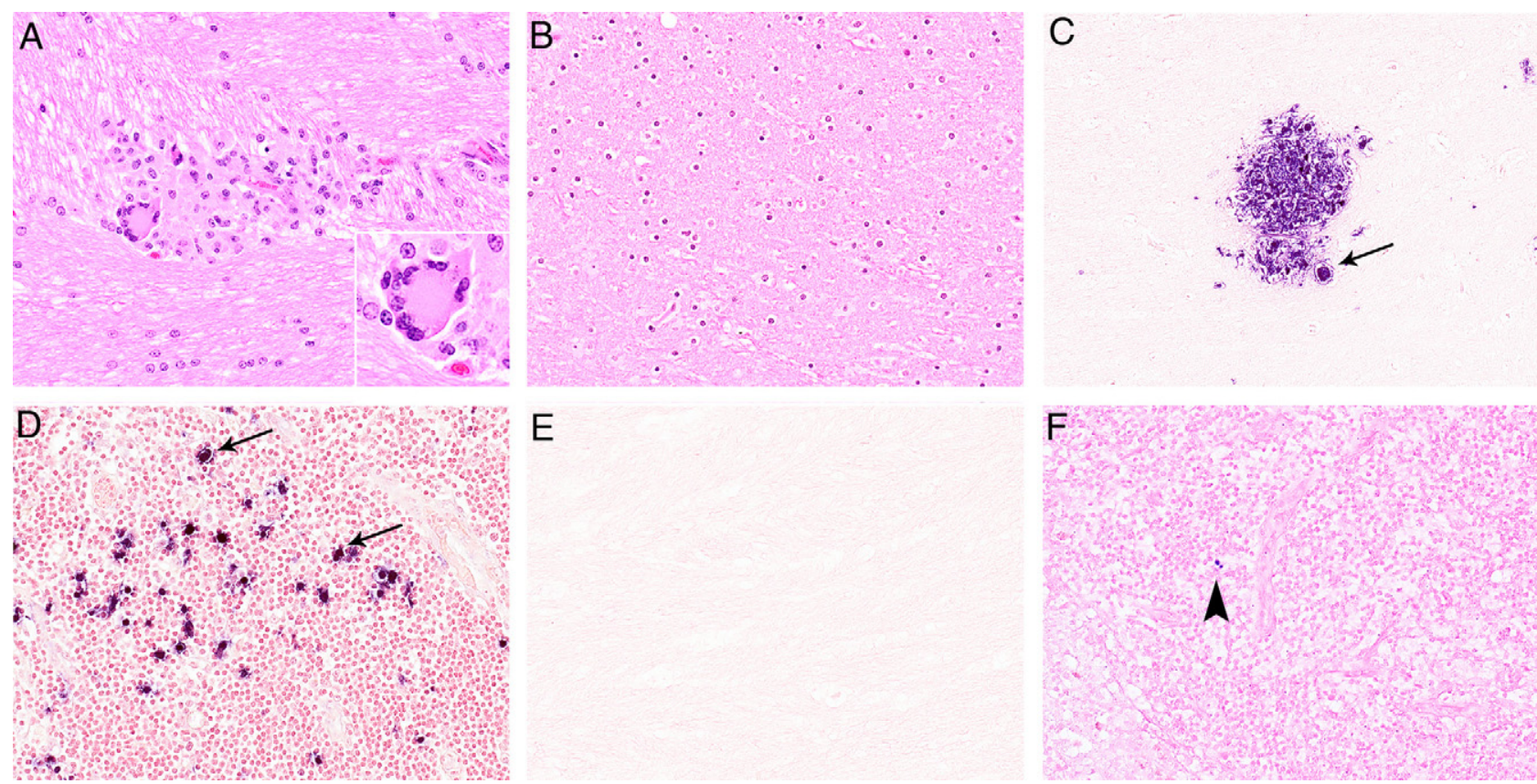

Figure 3. SIV RNA is localized in the lesions of untreated animals. A: Microglial nodule in a section of brain tissue from an untreated control, (H\&E, $\times 200)$. Inset: Higher magnification showing a multinucleated giant cell $(H \& E, \times 1000)$. B: Section of brain tissue from a treated animal with no lesions (H\&E, $\times 200)$. C: ISH for SIV RNA, showing productively infected cells (arrow) in the brain, and mesenteric lymph nodes (arrows; D) from untreated animals. NBT/BCIP chromogen (blue) with nuclear fast red counterstain $(\times 200)$. E: SIV RNA is not localized in brain sections, and rare infected mononuclear cells (arrowhead) are identified in the mesenteric lymph nodes (F) by ISH in monkeys that received CART.

tified the SIV copy numbers by real-time RT-PCR in total RNA isolated from bone marrow, spleen, and mesenteric, axillary, and inguinal lymph nodes. Tissue virus loads were significantly lower in bone marrow, spleen, mesenteric lymph node, and inguinal lymph node $(P<0.03)$ from animals that received CART than from controls (Figure 7, A-E). In light of the effect of CART on plasma viral loads, these data provide further evidence that short-term CART was effective in suppressing viral replication in peripheral lymphoid tissues and reducing systemic virus burden.

\section{TNF- $\alpha$ Expression in Brain and Lymphoid}

Tissues

TNF- $\alpha$ is a principle proinflammatory mediator of leniviral encephalitis; thus, we measured the absolute numbers of
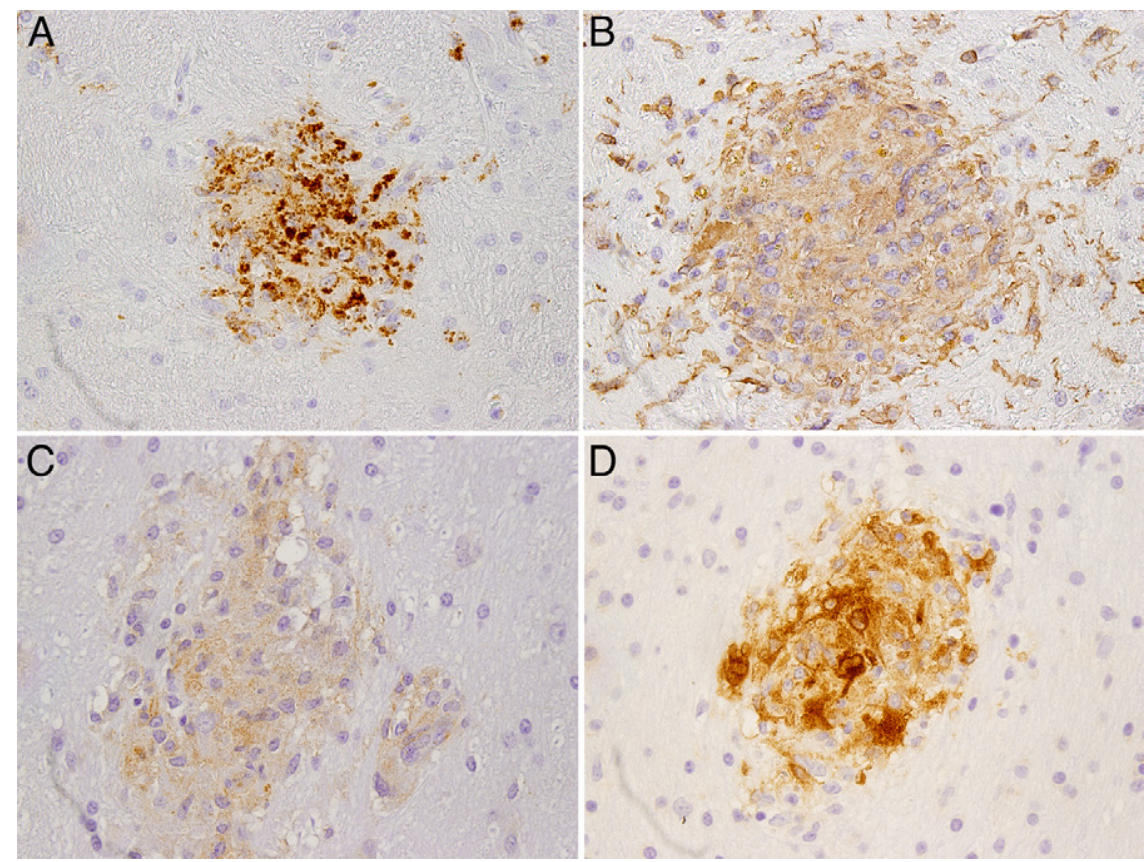

Figure 4. Brain lesions are composed of cells of macrophage lineage. Sections of brain tissue from an untreated infected control animal showing microglial nodules that are composed of cells expressing CD68 (A), which identifies activated macrophages/microglia; Iba-1 (B), expressed by microglia/macrophages; and HLA-DR (C). Localization of SIV major capsid protein p27 in a microglial nodule by IHC (D). Immunoperoxidase immunohistochemistry with DAB chromogen (brown) and hematoxylin counterstain $(\times 100)$. 

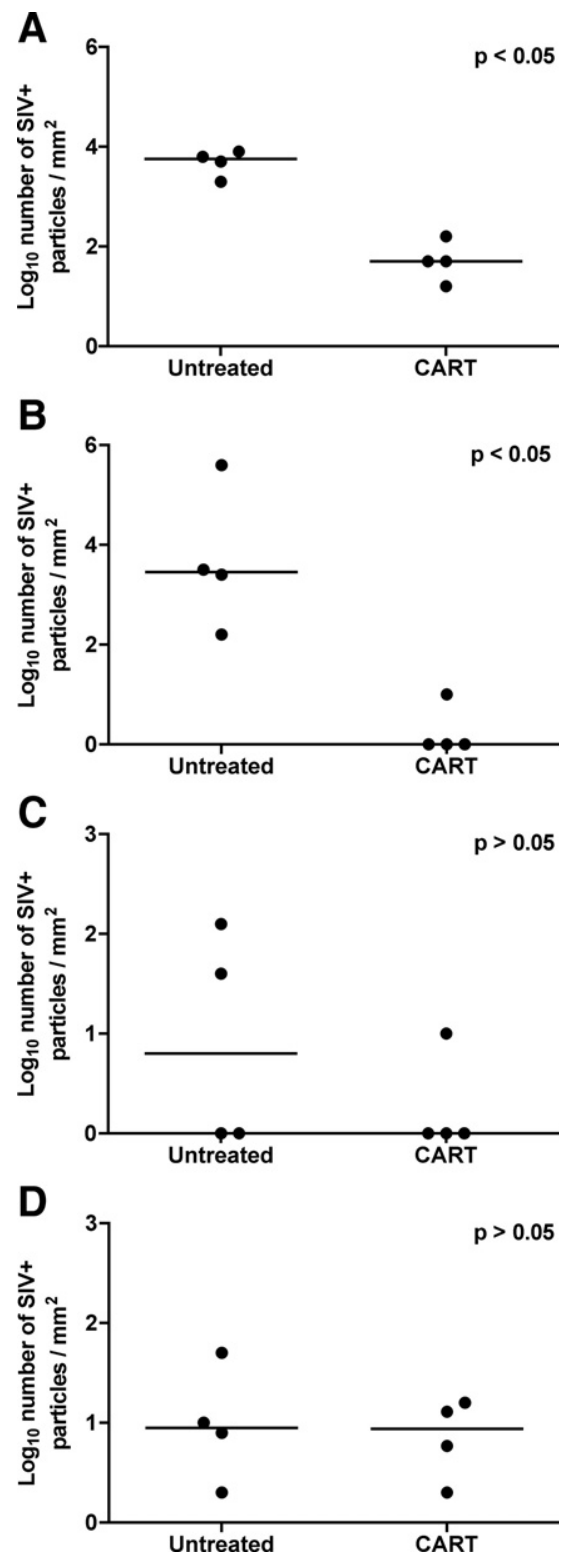

Figure 5. A: In situ hybridization for SIV RNA in brain. Quantitative image analysis for SIV RNA revealed significantly fewer SIV RNA particles in frontal cortex (A) and brainstem (B) from animals that received CART as compared with untreated controls $(P<0.05)$. Fewer SIV RNA particles were also localized in hippocampus $(\mathbf{C})$ and putamen $(\mathbf{D})$ from macaques that received CART as compared with untreated controls; however, the results were not significant. Horizontal bars indicate group median values.

TNF- $\alpha$ mRNA transcripts expressed in brain tissues from all eight animals by real-time RT-PCR to assess the impact of short-term CART on encephalitis. Significantly lower quantities of TNF- $\alpha$ mRNA transcripts were measured in the putamen of macaques that received CART than in controls $(P=0.03)$; however, there was no difference in TNF- $\alpha$ expression between treatment groups in the other regions of brain (Figure 8, A-E). To evaluate the effect of short-term CART on inflammation in systemic lymphoid tissue, we also measured TNF- $\alpha$ expression in RNA extracted from the spleen of all eight macaques; however, no differences in TNF- $\alpha$ mRNA expression were found in splenic tissue from treated animals versus un-

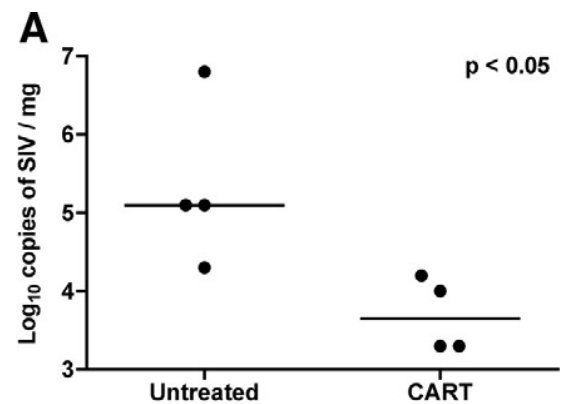

B
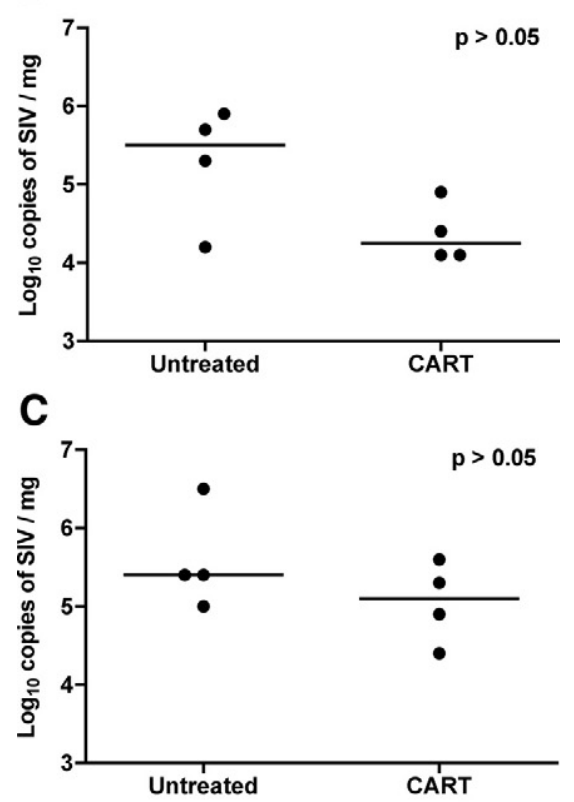

D

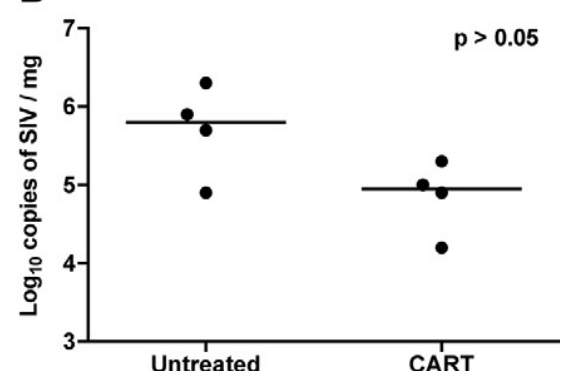

Figure 6. Virus burden in brain tissue measured by real-time RT-PCR. Lower quantities of SIV RNA were measured by real-time RT-PCR in the frontal cortex (A), brainstem (B), hippocampus $(\mathbf{C})$, and putamen (D) from animals that received CART as compared with untreated controls; however, the difference was only significant in the frontal cortex $(P<0.05)$. Results are reported as $\log _{10}$ copies of SIV RNA/mg of tissue; horizontal bars indicate group median values.

treated controls (Figure 8). These data suggest that short-term antiretroviral therapy did not significantly alter the general severity of systemic inflammation or encephalitis in CD8-depleted SIV-infected rhesus monkeys.

\section{Impact of CART on Brain Macrophage Populations}

Since activated perivascular macrophages and microglia are central to the pathogenesis of lentiviral encephalitis, 

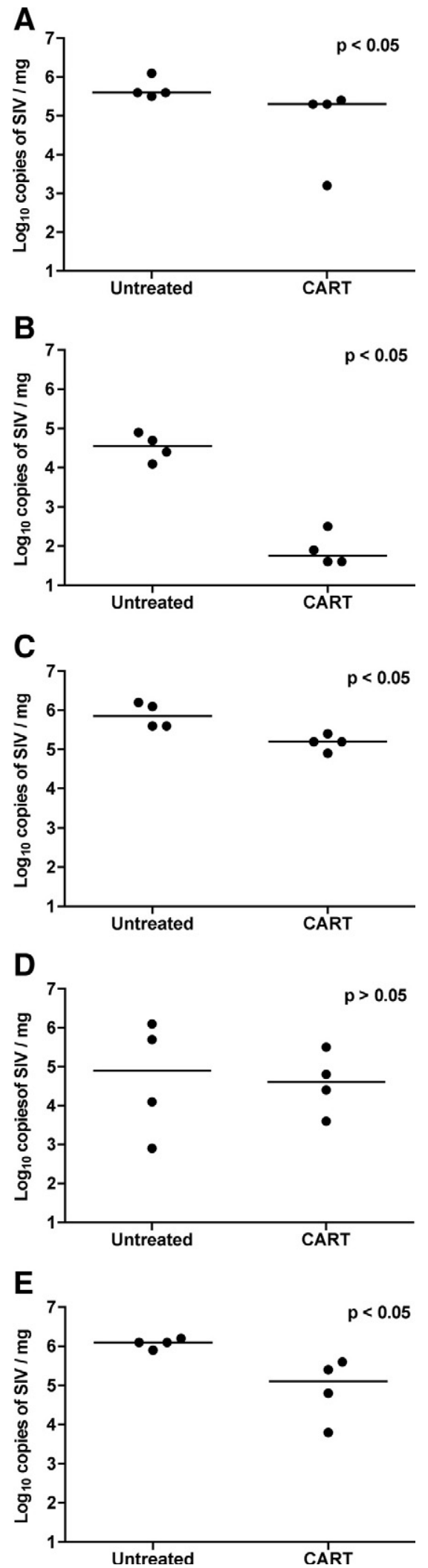

Figure 7. Virus burden in systemic lymphoid tissue measured by real-time RT-PCR. Lower quantities of SIV RNA were measured by real-time RT-PCR in the spleen (A), bone marrow (B), mesenteric lymph node (C), axillary lymph node (D), and inguinal lymph node (E) from macaques that received CART as compared with untreated controls. Differences were statistically significant in all tissue compartments $(P<0.05)$ except axillary lymph node. Results are reported as $\log _{10}$ copies of SIV RNA/mg of tissue; horizontal bars indicate group median values. we performed IHC for CD68 on sections of brain to localize activated macrophages and quantified immunoreactive cells by computer image analysis. Significant differences in the numbers of CD68-positive macrophages were not identified in any of the four regions of brain that were evaluated between antiretroviral treated animals and controls (Figure 9, A-D). Calcium binding adaptor protein, Iba- 1 is expressed by resting as well as activated microglia and its expression is increased in traumatic injury and under conditions of oxidative stress. In rhesus macaques, Iba-1 expression has been documented in resting and activated microglia in brain sections from normal and SIV-infected animals, respectively. ${ }^{58}$ Fewer Iba-1-reactive cells were present in the frontal cortex, brainstem, and putamen of animals in the CART group than in untreated animals, although these differences did not reach significance (Figure 10, A-D). These findings suggest that short-term antiretroviral therapy with nonpenetrating agents was modestly effective at reducing the numbers of activated macrophages and microglia in the CNS, but residual activation remained.

\section{Discussion}

Infection of Asian macaque monkeys with SIV is widely considered to be the best animal model for investigations of HIV neuropathogenesis. ${ }^{59}$ Nevertheless, very few studies addressing the impact of antiviral therapy on brain virus burden have been conducted in this model. ${ }^{60-62}$ This is partially because of the low incidence of SIVE, which at $18-32 \%$ is comparable to the incidence of HIVE observed in adult, untreated, HIV-infected humans. ${ }^{51,52,63}$ Consequently, various manipulations of the SIV/macaque model have been engineered in an attempt to increase the incidence of SIVE, including the isolation of neurovirulent SIV strains, ${ }^{64}$ coinfections with immunosuppressive and neurovirulent viruses, ${ }^{65}$ and depletion of CD8 lymphocytes to impair antiviral cellular immunity. ${ }^{66,67}$ In this study, we used the CD8-depletion model of accelerated SIVE in rhesus macaques to compare the impact of short-term CART on brain versus lymphoid tissue virus burden.

Short-term CART resulted in significant decreases in systemic virus burden, as revealed by viral load measurements in pre- and posttherapy plasma specimens. Moreover, significantly lower virus burdens were measured by real-time RT-PCR in four of five lymphoid tissues collected at necropsy from animals that received CART as compared with untreated animals. Notably, short-term CART was associated with lower brain virus burdens, despite the use of antiretroviral agents with poor CNS penetration. ${ }^{61,68}$ The tissue virus burden was significantly lower in frontal cortex using both ISH and RT-PCR methods and was significantly lower in brainstem by ISH and approached significance by RT-PCR $(P=0.11)$. These findings are in agreement with other studies in which brain virus burden has been measured in HIV-infected humans and SIV-infected macaques after therapy with antiretroviral regimens that included agents with poor BBB and blood-CSF barrier penetration pharmacokinetics. ${ }^{62,69}$ Moreover, these results help explain the previ- 
ously reported observation that monkeys that received CART in this study experienced near normalization of neuronal metabolism (NAA/Cr) as measured by in vivo MRI. ${ }^{54}$ In the context that neuronal injury was completely

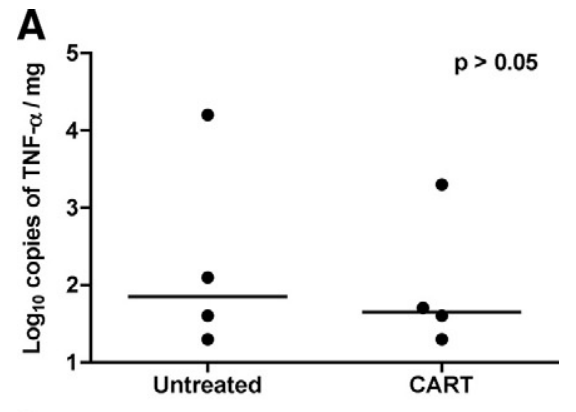

B

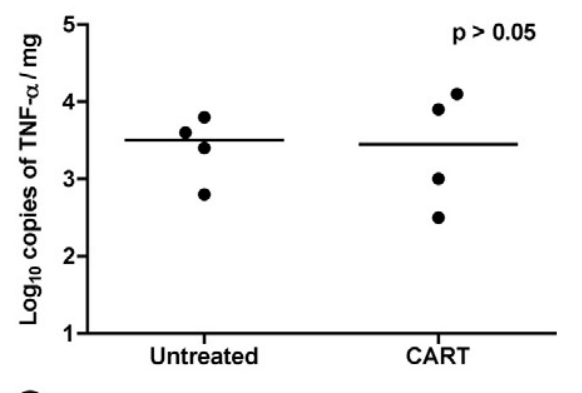

C

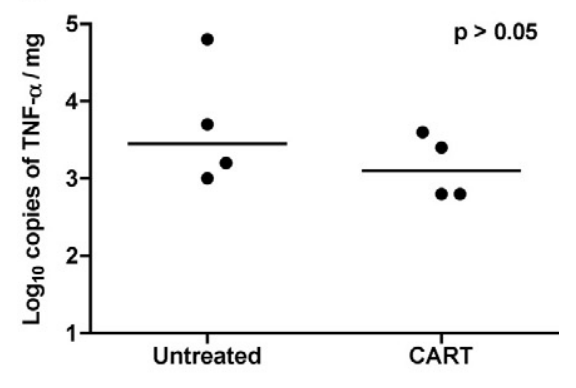

D

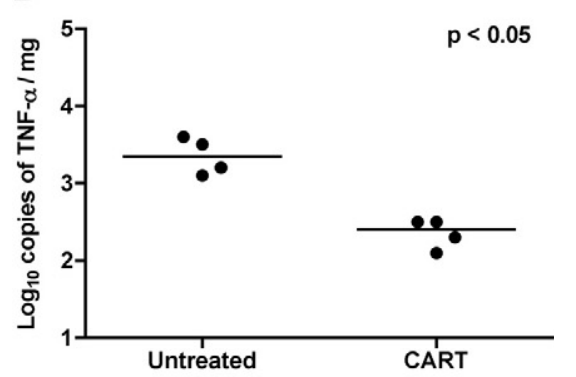

E

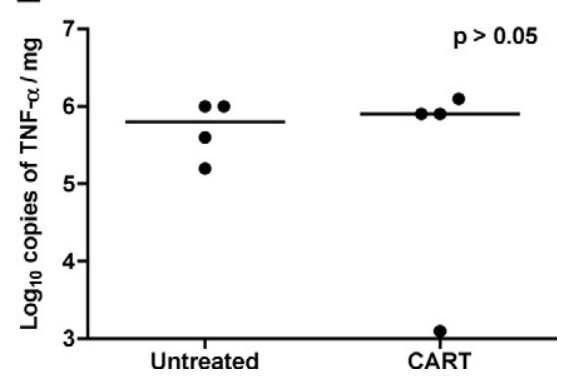

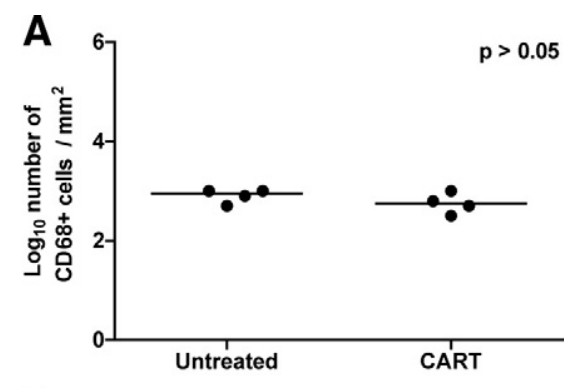
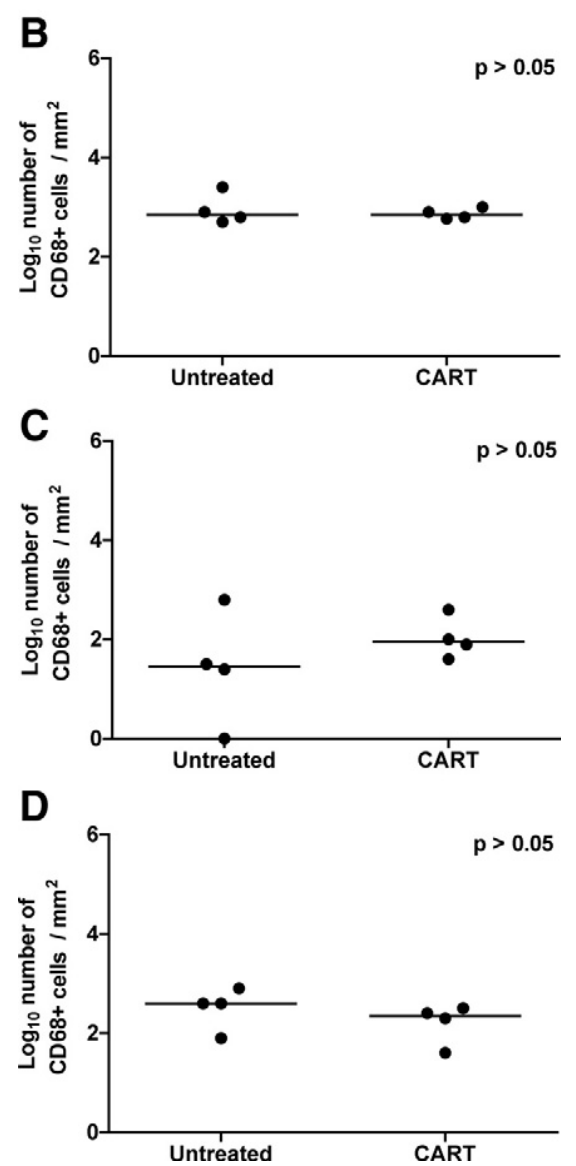

Figure 9. Immunohistochemistry for $\mathrm{CD} 68$ in brain. Quantitative immunohistochemistry for $\mathrm{CD} 68$ in frontal cortex (A), brainstem (B), hippocampus (C), and putamen (D) from untreated controls and macaques that received CART, reported as positive particles $/ \mathrm{mm}^{2}$ of tissue. Note that significant differences were not observed in any of the regions of brain. Horizontal bars indicate group median values.

reversed in these animals despite treatment with a regimen composed of low-potency antiretroviral agents, the results presented in this article are highly significant and help explain the previous clinical observations of marked improvement in cognitive disorders in HIV patients

Figure 8. TNF- $\alpha$ mRNA expression in spleen and brain tissue. TNF- $\alpha$ mRNA transcripts were measured by real-time RT-PCR in the frontal cortex (A), brainstem (B), hippocampus (C), and putamen (D) from untreated controls and animals that received CART. Significantly lower quantities of TNF- $\alpha$ RNA were measured in the putamen of macaques that received CART than in untreated controls $(P<0.05)$; however, the differences were not significant in the other regions of brain. Similar quantities of TNF- $\alpha$ mRNA were measured in spleen specimens from animals that received CART and untreated controls (E). Results are reported as $\log _{10}$ copies of TNF- $\alpha$ mRNA/mg of tissue; horizontal bars indicate group median values. 

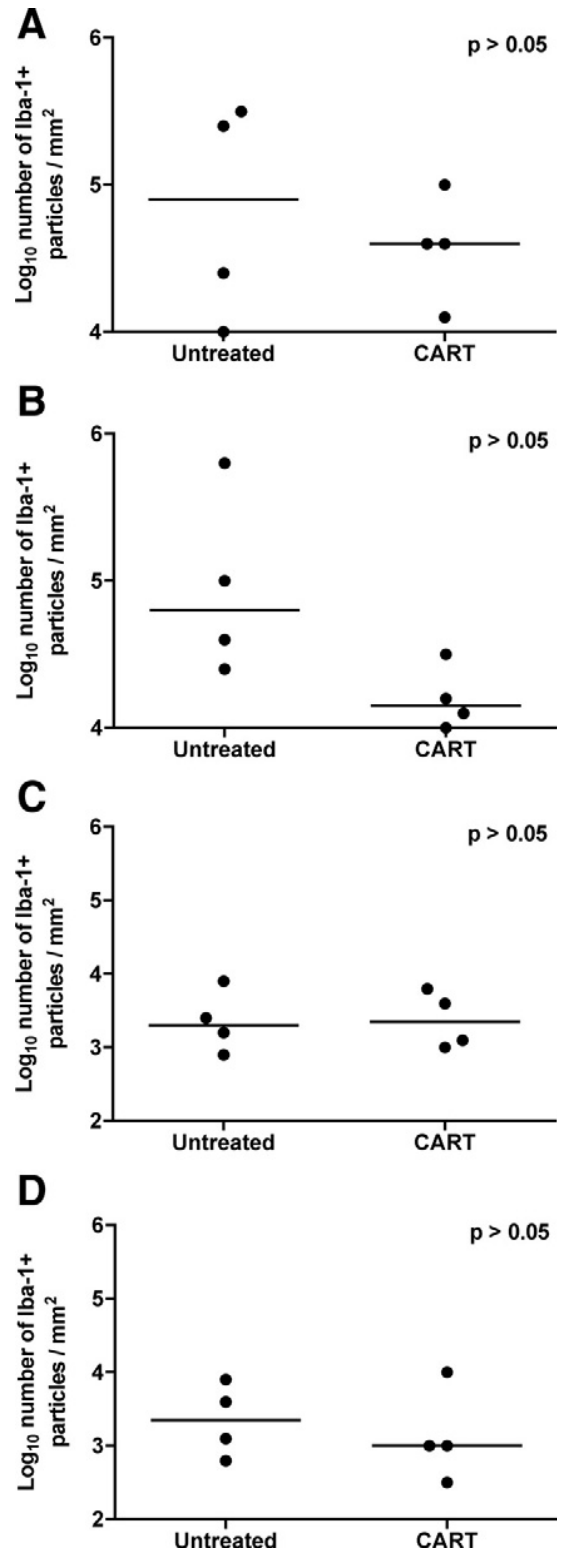

Figure 10. Immunohistochemistry for Iba-1 in brain. Quantitative immunohistochemistry for Iba-1 in frontal cortex (A), brainstem (B), hippocampus (C), and putamen (D) from untreated controls and macaques that received CART, reported as positive particles $/ \mathrm{mm}^{2}$ of tissue. Note that significant differences were not observed in any of the regions of brain. Horizontal bars indicate group median values.

treated with first generation (pre-HAART) antiretroviral drugs. ${ }^{70}$ Viral loads in CSF did not correlate with brain or plasma virus burdens; however, plasma viral loads correlated well with lymphoid tissue virus burdens. In light of the effect of CART on systemic virus burden, we hypothesize that the lower brain virus burdens measured in the treated animals were the result of decreased recruitment to the brain of new SIV-positive monocytes from the peripheral circulation. This hypothesis is supported by the findings of a related study (that used blood specimens from the same animals) which reported reduced frequencies of SIV-positive blood monocytes in animals that received CART. ${ }^{54}$
Cells of macrophage lineage, including blood-monocyte-derived perivascular macrophages and CNS-resident microglia, are central to all stages of HIVE/SIVE pathogenesis, serving as the vectors of lentiviral neuroinvasion, the principle targets of viral replication in the brain, and mediators of both direct and indirect mechanisms of neuropathogenic injury. ${ }^{71-74}$ Increased numbers of activated macrophages and microglia have repeatedly been correlated with active HIV and SIV replication in the brain ${ }^{45,47,75-78}$; thus, having observed lower levels of virus replication in the brains of macaques that received CART, we sought to investigate the impact of short-term antiretroviral treatment on the numbers and activation state of macrophages in the CNS using quantitative image analysis. SIV RNA was localized by ISH in perivascular macrophages, microglial nodules, and multinucleated giant cells in brain sections from untreated controls. The majority of cells in these lesions expressed the macrophage markers CD68 and Iba-1 as well as HLA-DR, suggesting that macrophages and microglia remain the principle targets of infection in the CD8-depletion model of accelerated SIVE. Surprisingly, although encephalitic lesions were not observed in monkeys that received CART, the numbers of cells expressing Iba-1 and CD68 in treated animals were similar to those measured in untreated animals. This may in part be due to the multifocal nature of the distribution of $\mathrm{CD} 8^{+}$ lesions and the random unbiased selection of analyzed fields. This may also reflect the longer turnover time of tissue macrophages in the CNS compartment ${ }^{79}$ and suggests that longer periods of therapy or the use of regimens that include CNS-penetrating agents may be required to accomplish reductions in brain macrophage numbers and activation state. In support of this hypothesis, Clements and colleagues ${ }^{60}$ reported significantly lower numbers of $\mathrm{CD}^{+} 8^{+}$cells in the brains of SIV-positive macaques after 32 weeks of combined PMPA/FTC therapy. Although CD68 expression was not measured in a parallel SIV negative control group in the current study, previous studies in both CD8-intact and depleted macaques have shown that CD68 is not expressed significantly in the CNS of animals that do not have SIVE ${ }^{45,80}$; thus, the presence of similar numbers of $\mathrm{CD}^{+} 8^{+}$macrophages in treated and control groups provides circumstantial evidence that SIVE was established in the brains of the animals in the CART group before the onset of therapy. Moreover, in vivo neuroimaging and MRS data showed evidence of neurodegeneration in the brains of all of the animals before onset of antiretroviral therapy. ${ }^{54}$ Collectively, these data suggest that the absence of encephalitic lesions and lower brain virus burdens observed in monkeys that received CART is attributable to short-term therapy and that macrophage/microglial activation may persist after reduction of virus in the brain parenchyma.

Lentiviral encephalitis is associated with severe dysregulation of cytokine and chemokine production in the CNS, including marked upregulation of TNF- $\alpha$ expression. ${ }^{81}$ TNF- $\alpha$ is produced primarily by activated macrophages and microglia in the brain, ${ }^{82-85}$ and its overexpression is thought to be a significant contributor to HIVE/ 
SIVE neuropathogenesis. ${ }^{73}$ TNF- $\alpha$ induces apoptosis of neurons in culture ${ }^{86}$ and has been shown to increase the permeability of endothelial cells in an in vitro BBB model, which suggests that it may facilitate transendothelial migration of monocytes, thus promoting neuroinvasion in vivo. ${ }^{87}$ In addition, TNF- $\alpha$ induces the expression of adhesion molecules (eg, ICAM-1, VCAM-1) and chemokines (MCP-1, CXCL10), which further induce the recruitment of monocytes to the CNS. ${ }^{88-90}$ Because of its central role in neuroinvasion and lentiviral neuropathogenesis, we measured TNF- $\alpha$ expression by real-time RT-PCR in brain specimens from treated and untreated monkeys. TNF- $\alpha$ mRNA expression was significantly lower in the putamen of macaques that received CART; however, the levels of expression were similar between treated and untreated animals in all other regions of the brain evaluated, as well as in spleen. These findings are in alignment with our observation that similar numbers of activated macrophages/microglia were present in brain sections from treated and untreated macaques and provide further evidence that the suppression of macrophage activation trails the control of viral replication by combined therapy with PMPA and RCV.

Two additional observations in macaques that received short-term CART merit discussion: 1) differences in lymphoid tissue histomorphology in all treated animals, and 2) encephalitic lesions that were atypical of SIVE in macaque number 8 . As opposed to untreated monkeys, greater follicular hyperplasia was observed in secondary lymphoid tissues from monkeys that received 28 days of CART, while multinucleated giant cells were conspicuously absent in lymphoid tissues from treated animals. Whether exaggeration of germinal center development correlates with reconstitution of the host immune response as a consequence of treatment or reflects further dysregulation of humoral immunity is beyond the scope of this study. However, the absence of multinucleated giant cells may be significant in that these cells are a consistent pathological feature of the encephalitic lesions induced by HIV and SIV.

Of greater interest are the multifocal encephalitic lesions observed in macaque number 8 ; these perivascular accumulations of primarily $\mathrm{B}$ lymphocytes were not associated with SIV replication, as confirmed by ISH and IHC. Moreover, the lesions were not only uncharacteristic of SIVE but were also atypical of the opportunistic pathogens that have been described in the CNS of SIV-infected macaques (eg, SV40, CMV, lymphocryptovirus, Mycobacteria). Immune reconstitution inflammatory syndrome (IRIS), which has been described in HIV-positive humans receiving HAART, has not yet been reported in SIV-infected monkeys treated with antiretroviral agents. In HIV-positive humans, IRIS most commonly presents as a paradoxical deterioration of clinical response in previously immunosuppressed patients who have experienced improvement in immune function shortly after the initiation of antiretroviral therapy. ${ }^{91}$ Instances of IRIS involving the CNS have been reported and have frequently been associated with progressive multifocal leukoencephalopathy (PML) or with Mycobacterial or Cryptococcal infections of the CNS; ${ }^{92-94}$ however, in some cases
CNS-IRIS presents as an exaggerated form of HIVE. ${ }^{95}$ The systemic response to HAART in patients who develop CNS-IRIS usually includes a significant increase in $\mathrm{CD}^{+}{ }^{+} \mathrm{T}$ cells and marked reductions in plasma HIV-1 RNA levels, and the brain lesions most often involve perivascular accumulations of $\mathrm{CD}^{+} \mathrm{T}$ cells. ${ }^{95,96}$ Changes in $\mathrm{CD}^{+}{ }^{+} \mathrm{T}$ cells during treatment were unavailable for case number 8; however, the SIV RNA levels in plasma from this animal decreased only 1.4 logs during treatment. Moreover, the brain lesions were dominated by $\mathrm{B}$ cells rather than cytotoxic $\mathrm{CD}^{+} \mathrm{T}$ cells, although the character of the inflammatory infiltrate may have been skewed by experimental CD8 depletion. Cumulatively, the available data would argue that this is not a case of CNS-IRIS in a nonhuman primate; thus, the etiology of these lesions remains unknown.

In summary, we found that four weeks of therapy with two nonpenetrating antiretroviral agents significantly reduced plasma viral loads and was correlated with lower virus burdens in four of five lymphoid tissues in CD8depleted SIV-infected rhesus macaques. In addition, significantly lower virus burdens were measured in two of four brain compartments by ISH quantitative image analysis and in one of four regions of brain by RT-PCR, while numbers of macrophages, activated macrophages, and TNF- $\alpha$ transcripts were similar between treated and control monkeys. Collectively, these data suggest that antiretroviral regimens composed of nonpenetrating agents can reduce brain virus burden and permit normalization of neuronal metabolism and function, provided significant reduction in systemic virus burden is achieved. These findings are highly significant in that they imply the existence of inherent mechanisms in the brain that allow full recovery of neurons even though virus burden, while reduced, is not completely eliminated from the CNS, and in the face of large numbers of activated macrophages/ microglia and high levels of TNF- $\alpha$ expression in the brain. Complete elimination of viral replication in the brain, resolution of encephalitic lesions, and suppression of macrophage and neuroimmune activation will likely require extended periods of therapy.

\section{Acknowledgments}

The following reagent was obtained through the $\mathrm{NIH}$ AIDS Research and Reference Reagent Program, Division of AIDS, National Institute of Allergy and Infectious Diseases, NIH: HIV-1 p24 monoclonal antibody (183H12-5C) from Dr. Bruce Chesebro and Kathy Wehrly. The reagent ARP3092, mAb to SIVnef (J5 \& C8, clone KK75) was obtained from the Programe EVA Centre for AIDS Reagents, NIBSC, UK, supported by the EC FP6/7 Europrise Network of Excellence, AIDS Vaccine Integrated Project and NGIN consortia and the Bill and Melinda Gates Global HIV Vaccine Research Cryorepository-Collaboration for AIDS Vaccine Discovery Project and was donated by Dr. K. Kent and C. Arnold. We thank Dr. Raymond Schinazi for providing PMPA and RCV. We thank Kristen Toohey for assistance with graphical preparations. 


\section{References}

1. Martin-Garcia J, Cao W, Varela-Rohena A, Plassmeyer ML, GonzalezScarano F: HIV-1 tropism for the central nervous system: brain-derived envelope glycoproteins with lower CD4 dependence and reduced sensitivity to a fusion inhibitor. Virology 2006, 346:169-179

2. Richman DD: HIV chemotherapy. Nature 2001, 410:995-1001

3. Brodt HR, Kamps BS, Gute P, Knupp B, Staszewski S, Helm EB: Changing incidence of AIDS-defining illnesses in the era of antiretroviral combination therapy. AIDS 1997, 11:1731-1738

4. Ferrando S, van Gorp W, McElhiney M, Goggin K, Sewell M, Rabkin $\mathrm{J}$ : Highly active antiretroviral treatment in HIV infection: benefits for neuropsychological function. AIDS 1998, 12:F65-70

5. Maschke M, Kastrup O, Esser S, Ross B, Hengge U, Hufnagel A: Incidence and prevalence of neurological disorders associated with HIV since the introduction of highly active antiretroviral therapy (HAART). J Neurol Neurosurg Psychiatry 2000, 69:376-380

6. Mocroft A, Katlama C, Johnson AM, Pradier C, Antunes F, Mulcahy F Chiesi A, Phillips AN, Kirk O, Lundgren JD: AIDS across Europe, 1994-98: the EuroSIDA study. Lancet 2000, 356:291-296

7. Moore RD, Chaisson RE: Natural history of HIV infection in the era of combination antiretroviral therapy. AIDS 1999, 13:1933-1942

8. Sacktor N, Lyles RH, Skolasky R, Kleeberger C, Selnes OA, Miller EN, Becker JT, Cohen B, McArthur JC: HIV-associated neurologic disease incidence changes: Multicenter AIDS Cohort Study, 1990-1998. Neurology 2001, 56:257-260

9. Husstedt IW, Frohne L, Bockenholt S, Frese A, Rahmann A, Heese C Reichelt D, Evers S: Impact of highly active antiretroviral therapy on cognitive processing in HIV infection: cross-sectional and longitudinal studies of event-related potentials. AIDS Res Hum Retroviruses 2002 18:485-490

10. Sacktor NC, Skolasky RL, Lyles RH, Esposito D, Selnes OA, McArthur JC: Improvement in HIV-associated motor slowing after antiretroviral therapy including protease inhibitors. J Neurovirol 2000, 6:84-88

11. Tozzi V, Balestra P, Galgani S, Narciso P, Ferri F, Sebastiani G, D'Amato C, Affricano C, Pigorini F, Pau FM, De Felici A, Benedetto A: Positive and sustained effects of highly active antiretroviral therapy on HIV-1-associated neurocognitive impairment. AIDS 1999 13:1889-1897

12. Tozzi V, Balestra P, Galgani S, Narciso P, Sampaolesi A, Antinori A, Giulianelli M, Serraino D, Ippolito G: Changes in neurocognitive performance in a cohort of patients treated with HAART for 3 years. J Acquir Immune Defic Syndr 2001, 28:19-27

13. Chang L, Ernst T, Leonido-Yee M, Witt M, Speck O, Walot I, Miller EN: Highly active antiretroviral therapy reverses brain metabolite abnormalities in mild HIV dementia. Neurology 1999, 53:782-789

14. Cinque $P$, Bestetti A, Morelli $P$, Presi S: Molecular analysis of cerebrospinal fluid: potential for the study of HIV-1 infection of the central nervous system. J Neurovirol 2000, 6 (Suppl 1):S95-S102

15. Eggers CC, van Lunzen J, Buhk T, Stellbrink HJ: HIV infection of the central nervous system is characterized by rapid turnover of viral RNA in cerebrospinal fluid. J Acquir Immune Defic Syndr Hum Retrovirol 1999, 20:259-264

16. Foudraine NA, Hoetelmans RM, Lange JM, de Wolf F, van Benthem $\mathrm{BH}$, Maas JJ, Keet IP, Portegies P: Cerebrospinal-fluid HIV-1 RNA and drug concentrations after treatment with lamivudine plus zidovudine or stavudine. Lancet 1998, 351:1547-1551

17. Gisslen M, Norkrans G, Svennerholm B, Hagberg L: The effect on human immunodeficiency virus type 1 RNA levels in cerebrospinal fluid after initiation of zidovudine or didanosine. J Infect Dis 1997 175:434-437

18. Gisslen M, Svennerholm B, Fuchs D, Hagberg L: Neurological efficacy of stavudine, zidovudine, and lamivudine. Lancet 1998, 352:402-403

19. Gisslen M, Svennerholm B, Norkrans G, Franzen C, Sall C, Svensson R, Oberg S, Hagberg L: Cerebrospinal fluid and plasma viral load in HIV-1-infected patients with various anti-retroviral treatment regimens. Scand J Infect Dis 2000, 32:365-369

20. Iftimovici E, Rabian C, Burgard M, Peytavin G, Rouzioux C, Viard JP: Longitudinal comparison of HIV-1 RNA burden in plasma and cerebrospinal fluid in two patients starting triple combination antiretroviral therapy. AIDS 1998, 12:535-537

21. Marra CM, Lockhart D, Zunt JR, Perrin M, Coombs RW, Collier AC:
Changes in CSF and plasma HIV-1 RNA and cognition after starting potent antiretroviral therapy. Neurology 2003, 60:1388-1390

22. Staprans S, Marlowe N, Glidden D, Novakovic-Agopian T, Grant RM, Heyes M, Aweeka F, Deeks S, Price RW: Time course of cerebrospinal fluid responses to antiretroviral therapy: evidence for variable compartmentalization of infection. AIDS 1999, 13:1051-1061

23. Stellbrink HJ, Eggers C, van Lunzen J, Albrecht H, Greten H: Rapid decay of HIV RNA in the cerebrospinal fluid during antiretroviral combination therapy. AIDS 1997, 11:1655-1657

24. Dore GJ, Correll PK, Li Y, Kaldor JM, Cooper DA, Brew BJ: Changes to AIDS dementia complex in the era of highly active antiretroviral therapy. AIDS 1999, 13:1249-1253

25. Masliah E, DeTeresa RM, Mallory ME, Hansen LA: Changes in pathological findings at autopsy in AIDS cases for the last 15 years. AIDS 2000, 14:69-74

26. Neuenburg JK, Brodt HR, Herndier BG, Bickel M, Bacchetti P, Price RW, Grant RM, Schlote W: HIV-related neuropathology, 1985 to 1999: rising prevalence of HIV encephalopathy in the era of highly active antiretroviral therapy. J Acquir Immune Defic Syndr 2002, 31:171-177

27. Vago L, Bonetto S, Nebuloni M, Duca P, Carsana L, Zerbi P D'Arminio-Monforte A: Pathological findings in the central nervous system of AIDS patients on assumed antiretroviral therapeutic regimens: retrospective study of 1597 autopsies. AIDS 2002, 16:1925-1928

28. Gray F, Chretien F, Vallat-Decouvelaere AV, Scaravilli F: The changing pattern of HIV neuropathology in the HAART era. J Neuropathol Exp Neurol 2003, 62:429-440

29. Langford TD, Letendre SL, Larrea GJ, Masliah E: Changing patterns in the neuropathogenesis of HIV during the HAART era. Brain Pathol 2003, 13:195-210

30. Chang L, Lee PL, Yiannoutsos CT, Ernst T, Marra CM, Richards T, Kolson D, Schifitto G, Jarvik JG, Miller EN, Lenkinski R, Gonzalez G, Navia BA: A multicenter in vivo proton-MRS study of HIVassociated dementia and its relationship to age. Neuroimage 2004, 23:1336-1347

31. McArthur JC, Haughey N, Gartner S, Conant K, Pardo C, Nath A Sacktor N: Human immunodeficiency virus-associated dementia: an evolving disease. J Neurovirol 2003, 9:205-221

32. Nath A, Schiess N, Venkatesan A, Rumbaugh J, Sacktor N, McArthur J: Evolution of HIV dementia with HIV infection. Int Rev Psychiatry 2008, 20:25-31

33. Albright AV, Soldan SS, Gonzalez-Scarano F: Pathogenesis of human immunodeficiency virus-induced neurological disease. J Neurovirol 2003, 9:222-227

34. Chang L, Ernst T, Witt MD, Ames N, Walot I, Jovicich J, DeSilva M, Trivedi N, Speck O, Miller EN: Persistent brain abnormalities in antiretroviral-naive HIV patients 3 months after HAART. Antivir Ther 2003, 8:17-26

35. Korber BT, Kunstman KJ, Patterson BK, Furtado M, McEvilly MM, Levy R, Wolinsky SM: Genetic differences between blood- and brainderived viral sequences from human immunodeficiency virus type 1-infected patients: evidence of conserved elements in the $\mathrm{V} 3$ region of the envelope protein of brain-derived sequences. J Virol 1994 68:7467-7481

36. Wong JK, Ignacio CC, Torriani F, Havlir D, Fitch NJ, Richman DD: In vivo compartmentalization of human immunodeficiency virus: evidence from the examination of pol sequences from autopsy tissues. J Virol 1997, 71:2059-2071

37. Chun TW, Fauci AS: Latent reservoirs of HIV: obstacles to the eradication of virus, Proc Natl Acad Sci USA: 1999, 96:10958-10961

38. Lambotte O, Deiva K, Tardieu M: HIV-1 persistence, viral reservoir, and the central nervous system in the HAART era. Brain Pathol 2003, 13:95-103

39. Pierson T, McArthur J, Siliciano RF: Reservoirs for HIV-1: mechanisms for viral persistence in the presence of antiviral immune responses and antiretroviral therapy. Annu Rev Immunol 2000, 18:665-708

40. Powderly WG: Current approaches to treatment for HIV-1 infection. J Neurovirol 2000, 6 (Suppl 1):S8-S13

41. Schrager LK, D'Souza MP: Cellular and anatomical reservoirs of HIV-1 in patients receiving potent antiretroviral combination therapy JAMA 1998, 280:67-71

42. Enting RH, Hoetelmans RM, Lange JM, Burger DM, Beijnen JH, Portegies P: Antiretroviral drugs and the central nervous system. AIDS 1998, 12:1941-1955 
43. Groothuis DR, Levy RM: The entry of antiviral and antiretroviral drugs into the central nervous system. J Neurovirol 1997, 3:387-400

44. Perno CF, Newcomb FM, Davis DA, Aquaro S, Humphrey RW, Calio $\mathrm{R}$, Yarchoan R: Relative potency of protease inhibitors in monocytes/ macrophages acutely and chronically infected with human immunodeficiency virus. J Infect Dis 1998, 178:413-422

45. O'Neil SP, Suwyn C, Anderson DC, Niedziela G, Bradley J, Novembre FJ, Herndon JG, McClure HM: Correlation of acute humoral response with brain virus burden and survival time in pig-tailed macaques infected with the neurovirulent simian immunodeficiency virus SIVsmmFGb. Am J Pathol 2004, 164:1157-1172

46. Wiley CA, Achim CL, Christopherson C, Kidane Y, Kwok S, Masliah E, Mellors J, Radhakrishnan L, Wang G, Soontornniyomkij V: HIV mediates a productive infection of the brain. AIDS 1999, 13:2055-2059

47. Williams KC, Corey S, Westmoreland SV, Pauley D, Knight H, deBakker C, Alvarez X, Lackner AA: Perivascular macrophages are the primary cell type productively infected by simian immunodeficiency virus in the brains of macaques: implications for the neuropathogenesis of AIDS. J Exp Med 2001, 193:905-915

48. Hurtrel B, Chakrabarti L, Hurtrel M, Maire MA, Dormont D, Montagnier L: Early SIV encephalopathy. J Med Primatol 1991, 20:159-166

49. Lackner AA, Smith MO, Munn RJ, Martfeld DJ, Gardner MB, Marx PA, Dandekar S: Localization of simian immunodeficiency virus in the central nervous system of rhesus monkeys. Am J Pathol 1991, 139:609-621

50. Ringler DJ, Hunt RD, Desrosiers RC, Daniel MD, Chalifoux LV, King NW: Simian immunodeficiency virus-induced meningoencephalitis: natural history and retrospective study. Ann Neurol 1988, 23 (Suppl):S101-S107

51. Baskin GB, Murphey-Corb M, Roberts ED, Didier PJ, Martin LN: Correlates of SIV encephalitis in rhesus monkeys. J Med Primatol 1992, 21:59-63

52. Westmoreland SV, Halpern E, Lackner AA: Simian immunodeficiency virus encephalitis in rhesus macaques is associated with rapid disease progression. J Neurovirol 1998, 4:260-268

53. Roberts ES, Zandonatti MA, Watry DD, Madden LJ, Henriksen SJ, Taffe MA, Fox HS: Induction of pathogenic sets of genes in macrophages and neurons in NeuroAIDS. Am J Pathol 2003, 162: 2041-2057

54. Williams K, Westmoreland S, Greco J, Ratai E, Lentz M, Kim WK Fuller RA, Kim JP, Autissier P, Sehgal PK, Schinazi RF, Bischofberger N, Piatak M, Lifson JD, Masliah E, Gonzalez RG: Magnetic resonance spectroscopy reveals that activated monocytes contribute to neuronal injury in SIV neuroAIDS. J Clin Invest 2005, 115:2534-2545

55. Suryanarayana K, Wiltrout TA, Vasquez GM, Hirsch VM, Lifson JD: Plasma SIV RNA viral load determination by real-time quantification of product generation in reverse transcriptase-polymerase chain reaction. AIDS Res Hum Retroviruses 1998, 14:183-189

56. Arnold C, Jenkins A, Almond N, Stott EJ, Kent KA: Monoclonal antibodies recognize at least five epitopes on the SIV Nef protein and identify an in vitro-induced mutation. AIDS Res Hum Retroviruses 1999, 15:1087-1097

57. Chesebro B, Wehrly K, Nishio J, Perryman S: Macrophage-tropic human immunodeficiency virus isolates from different patients exhibit unusual V3 envelope sequence homogeneity in comparison with T-cell-tropic isolates: definition of critical amino acids involved in cell tropism. J Virol 1992, 66:6547-6554

58. Borda JT, Alvarez X, Mohan M, Hasegawa A, Bernardino A, Jean S, Aye P, Lackner AA: CD163, a marker of perivascular macrophages, is up-regulated by microglia in simian immunodeficiency virus encephalitis after haptoglobin-hemoglobin complex stimulation and is suggestive of breakdown of the blood-brain barrier. Am J Pathol 2008, 172:725-737

59. Crews L, Lentz MR, Gonzalez RG, Fox HS, Masliah E: Neuronal injury in simian immunodeficiency virus and other animal models of neuroAIDS. J Neurovirol 2008, 14:327-339

60. Clements JE, Li M, Gama L, Bullock B, Carruth LM, Mankowski JL, Zink MC: The central nervous system is a viral reservoir in simian immunodeficiency virus-infected macaques on combined antiretroviral therapy: a model for human immunodeficiency virus patients on highly active antiretroviral therapy. J Neurovirol 2005, 11:180-189

61. Fox HS, Weed MR, Huitron-Resendiz S, Baig J, Horn TF, Dailey PJ, Bischofberger N, Henriksen SJ: Antiviral treatment normalizes neuro- physiological but not movement abnormalities in simian immunodeficiency virus-infected monkeys. J Clin Invest 2000, 106:37-45

62. Marcondes MC, Flynn C, Huitron-Rezendiz S, Watry DD, Zandonatti M, Fox HS: Early antiretroviral treatment prevents the development of central nervous system abnormalities in simian immunodeficiency virus-infected rhesus monkeys. AIDS 2009, 23:1187-1195

63. Kure K, Llena JF, Lyman WD, Soeiro R, Weidenheim KM, Hirano A, Dickson DW: Human immunodeficiency virus-1 infection of the nervous system: an autopsy study of 268 adult, pediatric, and fetal brains. Hum Pathol 1991, 22:700-710

64. Novembre FJ, De Rosayro J, O'Neil SP, Anderson DC, Klumpp SA, McClure HM: Isolation and characterization of a neuropathogenic simian immunodeficiency virus derived from a sooty mangabey. J Virol 1998, 72:8841-8851

65. Zink MC, Amedee AM, Mankowski JL, Craig L, Didier P, Carter DL, Munoz A, Murphey-Corb M, Clements JE: Pathogenesis of SIV encephalitis. Selection and replication of neurovirulent SIV. Am J Pathol 1997, 151:793-803

66. Schmitz JE, Kuroda MJ, Santra S, Sasseville VG, Simon MA, Lifton MA, Racz P, Tenner-Racz K, Dalesandro M, Scallon BJ, Ghrayeb J, Forman MA, Montefiori DC, Rieber EP, Letvin NL, Reimann KA: Control of viremia in simian immunodeficiency virus infection by CD8+ lymphocytes. Science 1999, 283:857-860

67. Williams K, Alvarez X, Lackner AA: Central nervous system perivascular cells are immunoregulatory cells that connect the CNS with the peripheral immune system. Glia 2001, 36:156-164

68. Schinazi RF, Boudinot FD, Ibrahim SS, Manning C, McClure HM, Liotta DC: Pharmacokinetics and metabolism of racemic 2', $3^{\prime}$ dideoxy-5-fluoro-3'-thiacytidine in rhesus monkeys. Antimicrob Agents Chemother 1992, 36:2432-2438

69. Langford D, Marquie-Beck J, de Almeida S, Lazzaretto D, Letendre S, Grant I, McCutchan JA, Masliah E, Ellis RJ: Relationship of antiretroviral treatment to postmortem brain tissue viral load in human immunodeficiency virus-infected patients. J Neurovirol 2006, 12:100-107

70. Price RW, Yiannoutsos CT, Clifford DB, Zaborski L, Tselis A, Sidtis JJ, Cohen B, Hall CD, Erice A, Henry K: Neurological outcomes in late HIV infection: adverse impact of neurological impairment on survival and protective effect of antiviral therapy. AIDS Clinical Trial Group and Neurological AIDS Research Consortium study team. AIDS 1999, 13:1677-1685

71. Garden GA: Microglia in human immunodeficiency virus-associated neurodegeneration. Glia 2002, 40:240-251

72. Gartner S: HIV infection and dementia. Science 2000, 287:602-604

73. Kaul M, Garden GA, Lipton SA: Pathways to neuronal injury and apoptosis in HIV-associated dementia. Nature 2001, 410:988-994

74. Williams KC, Hickey WF: Central nervous system damage, monocytes and macrophages, and neurological disorders in AIDS. Annu Rev Neurosci 2002, 25:537-562

75. Cosenza MA, Zhao ML, Si Q, Lee SC: Human brain parenchymal microglia express CD14 and CD45 and are productively infected by HIV-1 in HIV-1 encephalitis. Brain Pathol 2002, 12:442-455

76. Fischer-Smith T, Bell C, Croul S, Lewis M, Rappaport J: Monocyte/ macrophage trafficking in acquired immunodeficiency syndrome encephalitis: lessons from human and nonhuman primate studies. J Neurovirol 2008, 14:318-326

77. Kure K, Lyman WD, Weidenheim KM, Dickson DW: Cellular localization of an HIV-1 antigen in subacute AIDS encephalitis using an improved double-labeling immunohistochemical method. Am J Pathol 1990, 136:1085-1092

78. Wiley CA, Schrier RD, Nelson JA, Lampert PW, Oldstone MB: Cellular localization of human immunodeficiency virus infection within the brains of acquired immune deficiency syndrome patients. Proc Natl Acad Sci USA:1986, 83:7089-7093

79. Aquaro S, Calio R, Balzarini J, Bellocchi MC, Garaci E, Perno CF: Macrophages and HIV infection: therapeutical approaches toward this strategic virus reservoir. Antiviral Res 2002, 55:209-225

80. Bissel SJ, Wang G, Trichel AM, Murphey-Corb M, Wiley CA: Longitudinal analysis of monocyte/macrophage infection in simian immunodeficiency virus-infected. CD8+ T-cell-depleted macaques that develop lentiviral encephalitis. Am J Pathol 2006, 168:1553-1569

81. Brabers NA, Nottet HS: Role of the pro-inflammatory cytokines TNFalpha and IL-1beta in HIV-associated dementia. Eur $\mathrm{J}$ Clin Invest 2006, 36:447-458

82. Orandle MS, MacLean AG, Sasseville VG, Alvarez X, Lackner AA: 
Enhanced expression of proinflammatory cytokines in the central nervous system is associated with neuroinvasion by simian immunodeficiency virus and the development of encephalitis. J Virol 2002 , 76:5797-5802

83. Seilhean D, Kobayashi K, He Y, Uchihara T, Rosenblum O, Katlama C, Bricaire F, Duyckaerts C, Hauw JJ: Tumor necrosis factor-alpha, microglia and astrocytes in AIDS dementia complex. Acta Neuropathol 1997, 93:508-517

84. Sippy BD, Hofman FM, Wallach D, Hinton DR: Increased expression of tumor necrosis factor-alpha receptors in the brains of patients with AIDS. J Acquir Immune Defic Syndr Hum Retrovirol 1995, 10:511-521

85. Wesselingh SL, Takahashi K, Glass JD, McArthur JC, Griffin JW, Griffin DE: Cellular localization of tumor necrosis factor mRNA in neurological tissue from HIV-infected patients by combined reverse transcriptase/polymerase chain reaction in situ hybridization and immunohistochemistry. J Neuroimmunol 1997, 74:1-8

86. Downen M, Amaral TD, Hua LL, Zhao ML, Lee SC: Neuronal death in cytokine-activated primary human brain cell culture: role of tumor necrosis factor-alpha. Glia 1999, 28:114-127

87. Fiala M, Looney DJ, Stins M, Way DD, Zhang L, Gan X, Chiappelli F, Schweitzer ES, Shapshak P, Weinand M, Graves MC, Witte M, Kim KS: TNF-alpha opens a paracellular route for HIV-1 invasion across the blood-brain barrier. Mol Med 1997, 3:553-564

88. Collins T, Read MA, Neish AS, Whitley MZ, Thanos D, Maniatis T: Transcriptional regulation of endothelial cell adhesion molecules: NFkappa B and cytokine-inducible enhancers. FASEB J 1995, 9:899-909

89. Hurwitz AA, Lyman WD, Berman JW: Tumor necrosis factor alpha and transforming growth factor beta upregulate astrocyte expression of monocyte chemoattractant protein-1. J Neuroimmunol 1995, 57:193-198

90. Williams R, Yao H, Dhillon NK, Buch SJ: HIV-1 Tat co-operates with IFN-gamma and TNF-alpha to increase CXCL10 in human astrocytes. PLoS One 2009, 4:e5709

91. DeSimone JA, Pomerantz RJ, Babinchak TJ: Inflammatory reactions in HIV-1-infected persons after initiation of highly active antiretroviral therapy. Ann Intern Med 2000, 133:447-454

92. Johnson T, Nath A: Neurological complications of immune reconstitution in HIV-infected populations. Ann NY Acad Sci 1184:106-120

93. Gray F, Bazille C, Adle-Biassette H, Mikol J, Moulignier A, Scaravilli F: Central nervous system immune reconstitution disease in acquired immunodeficiency syndrome patients receiving highly active antiretroviral treatment. J Neurovirol 2005, 11 Suppl 3:16-22

94. Tan K, Roda R, Ostrow L, McArthur J, Nath A: PML-IRIS in patients with HIV infection: clinical manifestations and treatment with steroids. Neurology 2009, 72:1458-1464

95. Miller RF, Isaacson PG, Hall-Craggs M, Lucas S, Gray F, Scaravilli F, An SF: Cerebral CD8+ lymphocytosis in HIV-1 infected patients with immune restoration induced by HAART. Acta Neuropathol 2004 , 108:17-23

96. Venkataramana A, Pardo CA, McArthur JC, Kerr DA, Irani DN, Griffin JW, Burger P, Reich DS, Calabresi PA, Nath A: Immune reconstitution inflammatory syndrome in the CNS of HIV-infected patients. Neurology 2006, 67:383-388 